\title{
KONSERVASI BUKIT KARST \\ SEBAGAI TINDAKAN MITIGASI KEKERINGAN DI DAERAH TANGKAPAN HUJAN SUB SISTEM GEOHIDROLOGI BRIBIN-BARON-SEROPAN KARST GUNUNGSEWU
}

\author{
Oleh: \\ Arif Ashari \\ Jurusan Pendidikan Geografi, FIS UNY
}

\begin{abstract}
Abstrak
Karst selama ini dipandang sebagai kawasan yang gersang, berbatu, dan selalu menghadapi permasalahan kesulitan sumberdaya air (Haryono, 2001). Potensi sumberdaya air di kawasan karst ini sebenarnya cukup baik yang dipengauhi oleh input curah hujan yang besar, batugamping yang telah terkarstifikasi, serta morfologi perbukitan karst. Permasalahan selama ini adalah kesulitan akses sumberdaya air, yang sedikit banyak telah teratasi dengan berkembangnya ilmu pengetahuan dan teknologi kerekayasaan untuk mengakses sumberdaya air tersebut.

Permasalahan yang paling mengancam adalah bencana kekeringan, yaitu ketika kuantitas sumberdaya air menurun akibat berkurangnya input sumberdaya air dari hujan. Untuk menghadapi kekeringan pada saat kemarau panjang salah satu tindakan yang dapat diupayakan adalah menahan sumberdaya air selama mungkin di kawasan karst, yang secara alami dapat dilakukan dengan memanfaatkan fungsi penyimpanan air bukit karst.

Bukit karst memiliki peran yang sangat besar dalam siklus hidrologi di kawasan karst. Input sumberdaya air dari curah hujan di kawasan karst sebagian besar akan masuk ke retakan-retakan (epikarst) yang terdapat di permukaan kemudian tersimpan dalam rongga-rongga hasil pelarutan. Bukit karst umumnya mampu menyimpan air tiga hingga empat bulan setelah berakhirnya musim penghujan, yaitu dengan mengeluarkan air secara perlahan-lahan ke sistem sungai bawah tanah. Dengan adanya fungsi tersebut, bukit karst harus dilindungi untuk menghadapi kekeringan pada musim kemarau. Tindakan konservasi yang dapat dilakukan antara lain menjaga dan mengelola bukit karst sesuai peruntukannya dengan mengacu pada tipe kawasan karst, mengatur pertambangan batugamping, rehabilitasi lahan bekas tambang, mengelola zona epikarst dan ponor/luweng, serta melakukan pemberdayaan masyarakat kawasan karst.
\end{abstract}

Kata Kunci: Kawasan Karst, Konservasi, Bukit Karst, Kekeringan 
Konservasi Bukit Karst Sebagai Tindakan Mitigasi Kekeringan di Daerah Tangkapan Hujan Sub Sistem

Geohidrologi Bribin-Baron-Seropan, Karst Gunungsewu

\section{Pendahuluan}

Karst merupakan suatu medan dengan kondisi hidrologi yang khas sebagai akibat dari batuan yang mudah larut dan memiliki porositas sekunder yang berkembang baik (Ford dan Williams, 2007). Sifat hidrologis yang khas dengan berkembangnya sistem drainase bawah permukaan tersebut menyebabkan kawasan karst selama ini identik dengan kawasan yang gersang dan berbatu (Haryono, 2001 ${ }^{\mathrm{a}}$ ). Padahal potensi sumberdaya air kawasan karst khususnya di Pulau Jawa pada dasarnya sama dengan bentuklahan lainnya karena input curah hujan yang besarnya relatif merata. Permasalahan yang dihadapi selama ini adalah kesulitan akses sumberdaya air. Hal ini karena ketersediaan air di permukaan yang sangat kecil, dengan kualitas yang kurang baik. Sementara itu airtanah kawasan karst keberadaannya mengikuti sistem drainase vertikal sebagai hasil proses pelarutan batugamping, yang baru terkumpul pada titik yang dalam dari permukaan.

Permasalahan akses sumberdaya air sedikit banyak telah teratasi dengan perkembangan ilmu pengetahuan dan teknologi kerekayasaan dalam bidang eksploitasi sumberdaya airtanah karst. Proyek pemompaan sungai bawah tanah telah dilakukan antara lain di daerah aliran sungai (DAS) bawah tanah Bribin yang mampu mencukupi kebutuhan air hingga 70 liter per kapita per hari untuk 80.000 jiwa (Nestmann dkk, 2011). Dengan demikian, permasalahan utama berkaitan dengan sumberdaya air di kawasan karst saat ini terrutama lebih kepada potensi bencana kekeringan yang terjadi pada musim kemarau.

Sebagai negara kepulauan yang terletak diantara Samudera Pasifik dan Samudera Hindia, kondisi iklim di Indonesia sangat dipengaruhi oleh dinamika yang terjadi di kedua samudera tersebut. Anomali temperatur permukaan laut yang positif dan tinggi di Samudara Pasifik menyebabkan curah hujan yang ekstrim tinggi di bagian timur Pasifik dan sebaliknya ekstrim rendah di Indonesia. Peristiwa ini disebut sebagai El Nino yang ditandai musim kemarau panjang. Dampaknya adalah sumberdaya air permukaan di kawasan karst yang terbatas akan semakin berkurang hingga akhirnya habis sehingga ketersediaan air bagi kebutuhan masyarakat juga sangat terbatas (Brunsch, 2011). Adapun simpanan air bawah permukaan masih tersedia karena pengaruh karakteristik akuifer karst yang mampu menyipan dan menahan air dalam waktu lama. Dalam hal ini bukit karst memegang peranan sangat penting melalui fungsi retakanretakan epikarst dekat permukaan yang dapat menyimpan air. Selain itu air yang tersimpan tidak dapat teratus dengan cepat ke sistem sungai bawah tanah karena batugamping yang belum terlarut di bawah zona epikarst bersifat kedap air. Air hanya dapat teratus melalui celah-celah batuan (kekar dan sesar) sehingga aliran air terjadi secara perlahan-lahan dalam waktu yang lama (Haryono, 2001 ${ }^{\mathrm{a}}$ ). 
Sub-sistem Bribin-Baron-Seropan merupakan salah satu unit geohidrologi yang ada di Karst Gunungsewu. Sub sistem ini sebenarnya merupakan sungai bawah tanah Bribin yang merupakan sistem sungai bawah tanah terbesar di Karst Gunungsewu dengan debit mencapai 8.000 liter/detik (Haryono, 2011). Saat ini pemompaan air dari sungai bawah tanah ini telah banyak dilakukan untuk mencukupi kebutuhan sumberdaya air di wilayah sekitarnya. Daerah tangkapan air Sungai Bribin merupakan bentang alam bertopografi karst dengan ciri khusus berupa ribuan bukit-bukit sisa proses pelarutan (Adji, 2010). Debit air Sungai Bribin yang bersifat perenial dikendalikan oleh perbukitan karst ini.

Karst Gunungsewu memiliki rata-rata curah hujan 2.000 mm/tahun. Variasi curah hujan tahun 1952 hingga 2009 menunjukkan kecenderungan terjadinya periode ulang peristiwa El Nino. Artinya bencana kekeringan masih terus menjadi ancaman di masa mendatang. Antara tahun 2002 hingga 2009 curah hujan tahunan selalu berada di bawah $2.000 \mathrm{~mm}$ (Brunsch, 2011). Akan tetapi sejak tahun 2010 hingga awal tahun 2012 terjadi sebaliknya, yaitu anomali iklim La Nina (anti El Nino) yang ditandai oleh hujan yang melimpah. Keadaan ini dapat meningkatkan potensi sumberdaya air untuk menghadapi El Nino dan bencana kekeringan pada masa yang akan datang. Untuk itu kelestarian bukit karst sebagai penyimpan sumberdaya air dan pemegang fungsi regulator sistem hidrologi Kawasan Karst Gunungsewu, khususnya sub-sistem Bribin-BaronSeropan perlu dijaga dengan melakukan berbagai tindakan konservasi.

\section{Nilai Hidrologis Bukit Karst}

Bukit karst baik yang berbentuk kerucut (kegelkarst) maupun berbentuk menara (turmkarst) memiliki kesamaan dalam proses yang bekerja yaitu proses pelarutan. Pelarutan menghasilkan rongga-rongga yang saling berhubungan (protocave) membentuk porositas sekunder. Pelarutan terbesar terjadi dekat permukaan yang disebabkan oleh daya larut air yang semakin menurun dalam perjalannya ke bawah akibat bertambahnya konsentrasi karbonat yang terlarut hingga mencapai kejenuhan pada kedalaman 30 hingga 50 meter. Ronggarongga tersebut sebagian terisi oleh tanah. Rongga-rongga pelarutan pori-pori tanah dan pori-pori antara butir batuan secara bersama-sama berfungsi sebagai penyimpan air (Haryono, 2000 ). Kapasitas penyimpanan terbesar terdapat pada rongga hasil pelarutan, kemudian pori-pori endapan isian tanah, dan pori-pori batuan seperti ditujukkan oleh Tabel 1.

Kandungan air dari endapan isian di bukit karst Kabupaten Gunungkidul dari $21,42 \%$ hingga 34,93\%. Nilai tersebut relatif besar. Besarnya kandungan air 
endapan isian disebabkan oleh tekstur endapan yang geluh lempung debuan hingga lempung. Konduktivitas hidraulik sangat lambat yaitu $10^{-9}-10^{-4}$ meter/detik hal ini merupakan bagian dari fungsi regulator sistem hidrologi kawasan karst, meskipun porositas sekunder besar akuifer karst tetap mampu menyisakan air di musim kemarau untuk mensuplai sungai bawah tanah sehingga dapat mengalir sepanjang tahun (perenial). Disamping itu air yang tersimpan di endapan isian tidak dapat teratus dengan cepat ke sistem sungai bawah tanah karena batugamping yang belum terlarut bersifat kedap air. Dengan demikian rongga-rongga pelarutan dan endapan isian berfungsi sebagai tandon air (Haryono, 2001 $\left.{ }^{\mathrm{a}}\right)$.

Tabel 1. Porositas Bukit Karst di Kabupaten Gunungkidul

\begin{tabular}{|l|l|l|l|l|}
\hline \multirow{2}{*}{ Tipe karst } & \multicolumn{1}{|c|}{ Karakteristik } & Batuan & $\begin{array}{l}\text { Rongga } \\
\text { pelarutan }\end{array}$ & $\begin{array}{l}\text { Endapan } \\
\text { isian }\end{array}$ \\
\cline { 3 - 5 } $\begin{array}{l}\text { Karst poligonal } \\
\text { (Kec Panggang) }\end{array}$ & $\begin{array}{l}\text { Batugamping terumbu yang } \\
\text { keras dan dangkal, karren dan } \\
\text { rongga pelarutan intensif, } \\
\text { dijumpai banyak mataair }\end{array}$ & $1.1-14.0$ & $22-52$ & $40-58.9$ \\
\hline $\begin{array}{l}\text { Karst labirin } \\
\text { (Kec Saptosari } \\
\text { dan Tepus) }\end{array}$ & $\begin{array}{l}\text { Batugamping terumbu yang } \\
\text { keras dan dalam, karren dan } \\
\text { rongga pelarutan intensif, tidak } \\
\text { terdapat mataair }\end{array}$ & $13-16.6$ & $22-52$ & $36.6-40.2$ \\
\hline $\begin{array}{l}\text { Karst tower- } \\
\text { cone } \\
\text { (Kec Ponjong) }\end{array}$ & $\begin{array}{l}\text { Batugamping berlapis, lunak dan } \\
\text { dalam, karren tidak berkembang } \\
\text { baik, bukit terpencar dengan } \\
\text { dataran planasi, tidak ditemukan } \\
\text { mataair }\end{array}$ & $\begin{array}{l}23.1- \\
48.2\end{array}$ & $<10$ & $20.6-31.9$ \\
\hline
\end{tabular}

Sumber: Haryono $\left(2000^{\mathrm{a}}\right)$

Dari uraian di atas dapat disimpulkan bahwa rongga-rongga hasil pelarutan di permukaan bukit karst berperan sebagai simpanan utama airtanah karst. Zona ini disebut zona epikarst (Gambar 1), yaitu lapisan dimana terdapat konsentrasi air hasil infiltrasi air hujan (Adji, 2010). Epikarstic zone atau subcutaneous zone adalah zone teratas yang tersingkap dari batuan karst yang memiliki permeabilitas dan porositas karena proses pelebaran celah pada zona ini merupakan yang paling tinggi dibanding lapisan-lapisan yang lain, dengan demikian dapat berperan sebagai media penyimpanan yang baik (Klimchouk, 1997 dalam Adji, 2010). Zona ini berperan sebagai penyedia aliran dasar di sungai bawah tanah bahkan pada periode kekeringan yang sangat panjang (Adji, 2010). 
Bagaimana peran dari bukit karst dan zona epikarst, sehingga airtanah di daerah karst dapat dipertahankan untuk memenuhi kebutuhan sepanjang tahun, bahkan pada periode kekeringan yang panjang? Dalam sistem hidrologi karst dikenal dua macam tipe aliran yaitu conduit dan diffuse (Ford dan Williams, 2007). Aliran conduit bergerak dengan cepat melalui lorong-lorong yang besar berukuran $10^{2}$ hingga $10^{4} \mathrm{~mm}$ atau lebih. Sedangkan aliran diffuse mengisi sungai bawah tanah secara seragam dan perlahan-lahan melalui retakan-retakan yang berukuran $10^{-3}$ hingga $10 \mathrm{~mm}$ sebagai aliran infiltrasi dari zona simpanannya di permukaan bukit karst (Adji, 2010).

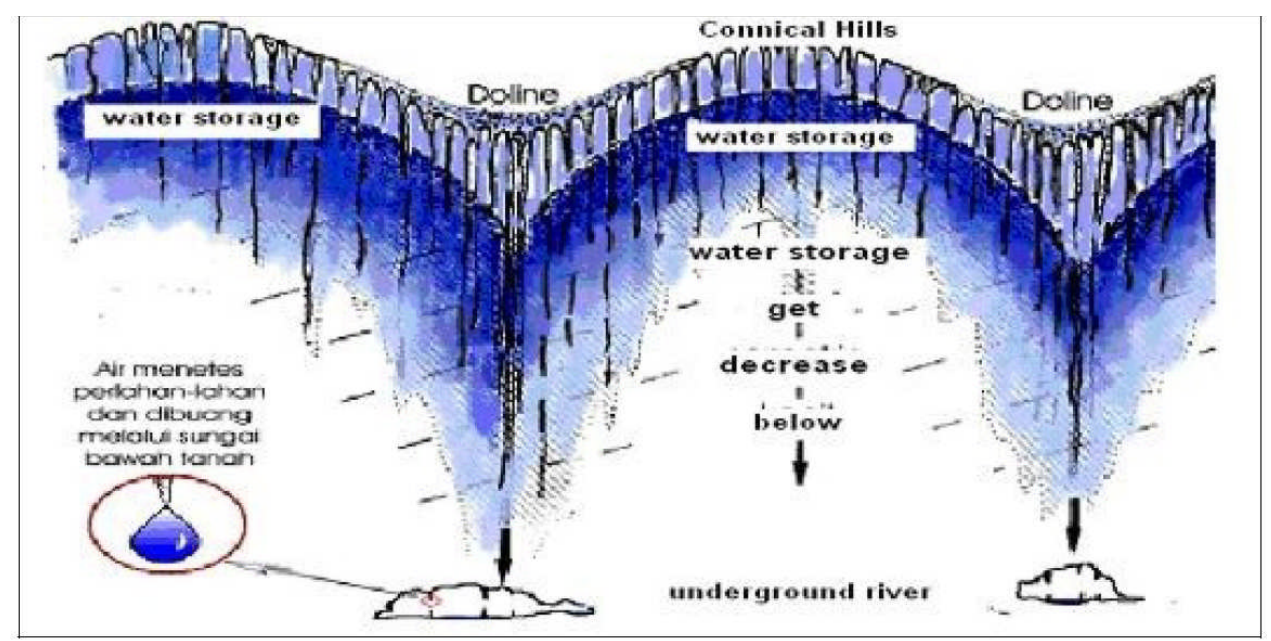

Gambar 1. Zona epikarst yang berperan sebagai penyimpan utama airtanah di daerah karst (Ford dan Williams, 1995 dalam Haryono, 2001ª)

Dengan demikian dapat diketahui bahwa air yang tersimpan pada zona epikarst akan dialirkan sebagai aliran diffuse kemudian mengisi sungai bawah tanah. Aliran diffuse ini merupakan aliran dasar yang berperan penting sebagai komponen penyedia debit pada saat musim kemarau. Oleh karena itu sungai bawah tanah tidak kering walaupun pada musim kemarau. Sebagai contoh Sungai Bawah Tanah Bribin pada puncak kemarau (Agustus-September) dimana tidak ada hujan sama sekali dan tidak ada masukan aliran dari permukaan debitnya masih cukup tinggi (1600 liter/detik), yaitu semuanya diperoleh dari aliran diffuse ini (Adji, 2010). 


\section{Kondisi Daerah Tangkapan Hujan Sub-Sistem Bribin-Baron-Seropan dan Ancaman Kekeringan Yang Dihadapinya}

Karst Gunungsewu merupakan salah satu bentanglahan karst tropis yang terdapat di Pulau Jawa. Membentang sepanjang 85 kilometer di tiga provinsi yaitu DIY, Jawa Tengah dan Jawa Timur dengan total luas wilayah $1300 \mathrm{~km}^{2}$. Kawasan Karst Gunungsewu terbentuk dari batugamping Neogen (Miosen Tengah hingga Pliosen Atas) Formasi Wonosari - Punung (tmwp). Karstifikasi yang terjadi di kawasan karst Gunungsewu menghasilkan kenampakan yang khas dijumpai pada karst tropis yaitu bukit karst/kegelkarst (Haryono, 2011). Menurut Haryono dan Day (2004) bukit karst yang terdapat di kawasan Karst Gunungsewu dibedakan menjadi bukit karst labirin, bukit karst poligonal, dan bukit karst residual. Wilayah Karst Gunungsewu ditunjukkan oleh Gambar 2.

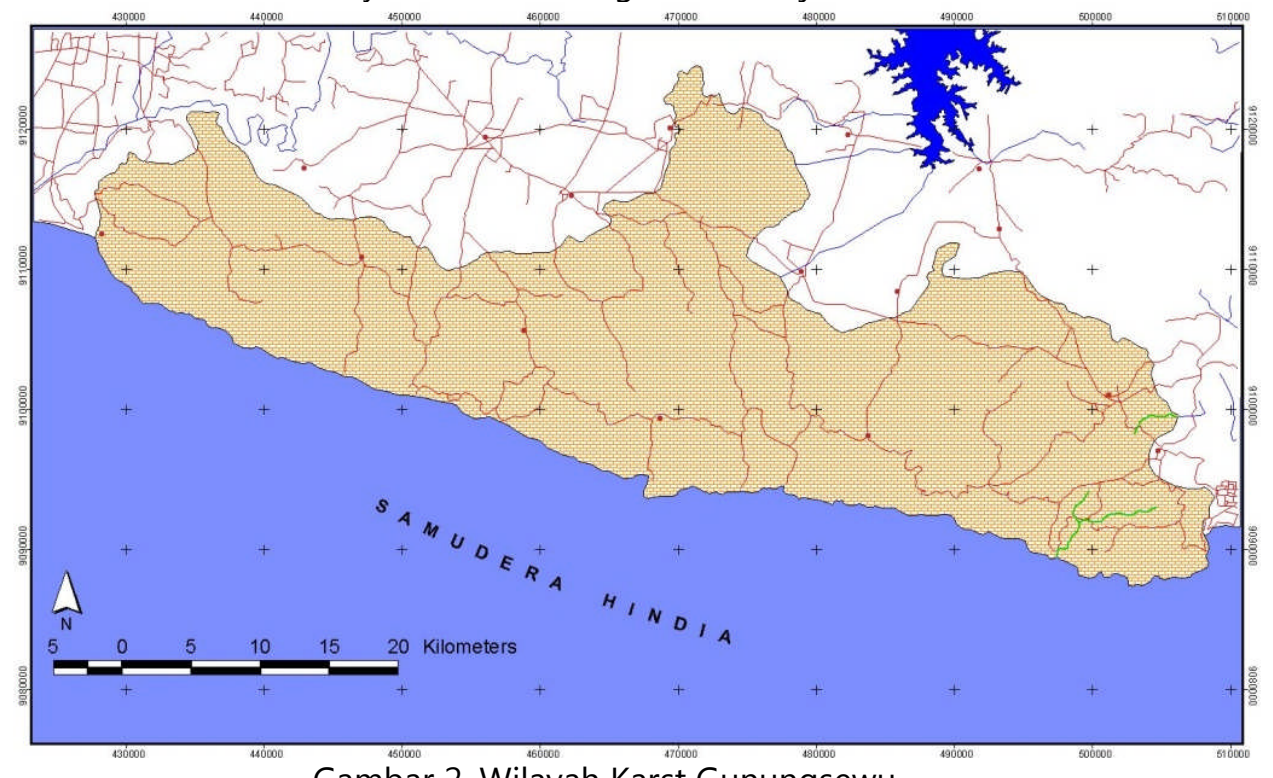

Gambar 2. Wilayah Karst Gunungsewu

Karst Gunungsewu terbagi menjadi lima sub sistem geohidrologi (Gambar 3) yaitu Sub-sistem Panggang, Sub Sistem Bribin-Baron-Seropan, Sub-Sistem Ponjong, Sub-sistem Baturetno-Giritontro, dan Sub-sistem Donorojo-Pringkuku (Haryono, 2011). Sub Sistem Bribin-Baron-Seropan memiliki ciri tersendiri yaitu berupa sistem daerah aliran sungai (DAS) Bribin-Baron, yang merupakan DAS bawah tanah yang besar. Sungai bawah tanah Bribin-Baron mengalir ke arah baratdaya dan bermuara di Pantai Baron. Menurut Mac Donald and Partners 
(1984) DAS Bribin dengan anak-anak sungainya memiliki debit yang cukup besar antara lain Bribin (1.500 liter/detik), Seropan (400 liter/detik ), Baron (8.000 liter/detik), dan Ngobaran (150 liter/detik). Selain itu terdapat pula belasan sungai bawah tanah dengan debit dibawah 100 liter/detik. Di Sub-sistem BribinBaron-Seropan juga terdapat banyak mataair. Beberapa diantaranya memiliki debit yang tinggi yaitu di Ngobaran (180 liter/detik), Baron (8.200 liter/detik), Slili (50 liter/detik), dan Sundak (200 liter/detik).

Daerah tangkapan air di bagian hulu Sungai Bribin-Baron merupakan bentanglahan karst dengan ciri khusus berupa ribuan bukit sisa proses pelarutan. Mengacu kepada Haryono dan Day (2004) tipe bukit karst di daerah tangkapan air ini adalah residual yang nampak sebagai dataran planasi dengan kubah karst di tengahnya. Morfologi karst tower ini merupakan kelanjutan dari perkembangan karst tipe poligonal (Haryono dan Day, 2004; Adji, 2010). Daerah tangkapan air Sungai Bribin-Baron ditunjukkan oleh Gambar 4.

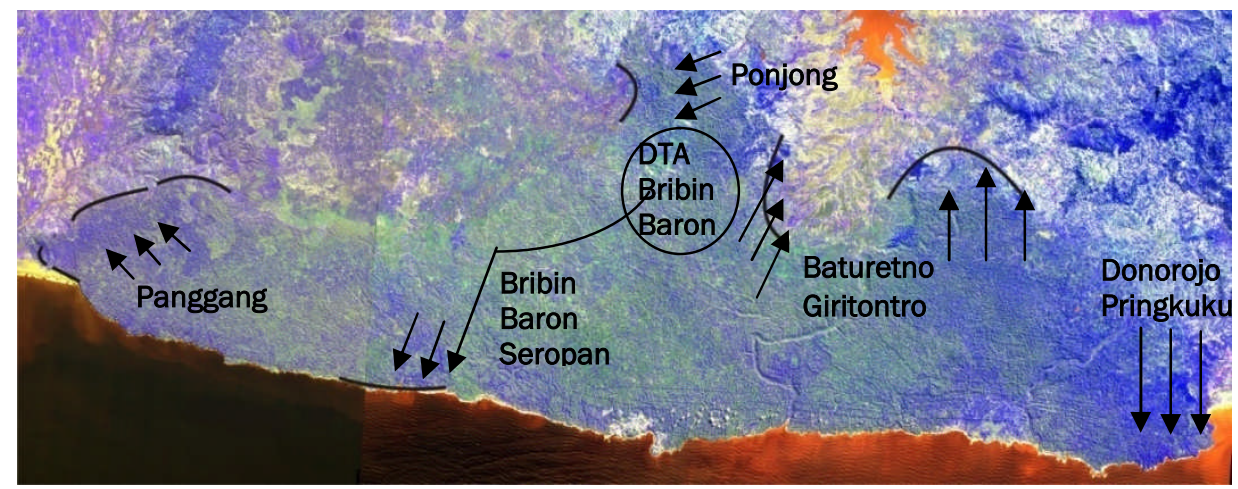

Gambar 3. Sistem Geohidrologi di wilayah Karst Gunungsewu (Haryono, 2011)

Menurut Adji dan Nurjani (1999 dalam Adji, 2010) daerah tangkapan hujan bagian hulu Sungai Bribin-Baron meliputi wilayah seluas $55 \mathrm{~km}^{2}$, berbentuk tapal kuda, yang secara administratif sebagian besar wilayahnya berada di Kecamatan Ponjong. Terdapat 39 goa vertikal dan horizontal yang memiliki air dengan debit aliran yang bervariasi. Sebagian besar goa mempunyai sistem yang tergabung dengan Goa Bribin sebagai sistem utama sungai bawah tanah. Menurut Adji (2010) beberapa goa yang telah teridentifikasi sebagai bagian dari Sungai Bribin di bagian hulu, berturut-turut sesuai arah aliran, antara lain Goa Jomblangan (debit airtanah 37 liter/detik), kemudian Goa Gilap (40 liter/detik), Goa Jomblangbanyu (350 liter/detik), Luweng Jurangjero (1200 liter/detik), dan Goa Bribin (1500 liter/detik). 
Hujan merupakan sumber input sumberdaya air utama di Kawasan Karst Gunungsewu termasuk kawasan non-karst di sekitarnya yang turut memberikan input sumberdaya air ke Karst Gunungsewu. Data curah hujan tahun 1952 hingga 2009 menunjukkan hujan tahunan sebagian besar (69\%) berada pada rentang 1251 hingga $2500 \mathrm{~mm}$. Selain itu peristiwa hujan yang ekstrim (ekstrim rendah dibawah $750 \mathrm{~mm}$ dan ekstrim tinggi diatas $4000 \mathrm{~mm}$ ) juga pernah terjadi akan tetapi relatif sedikit dan tidak merata (Brunsch dkk, 2011).

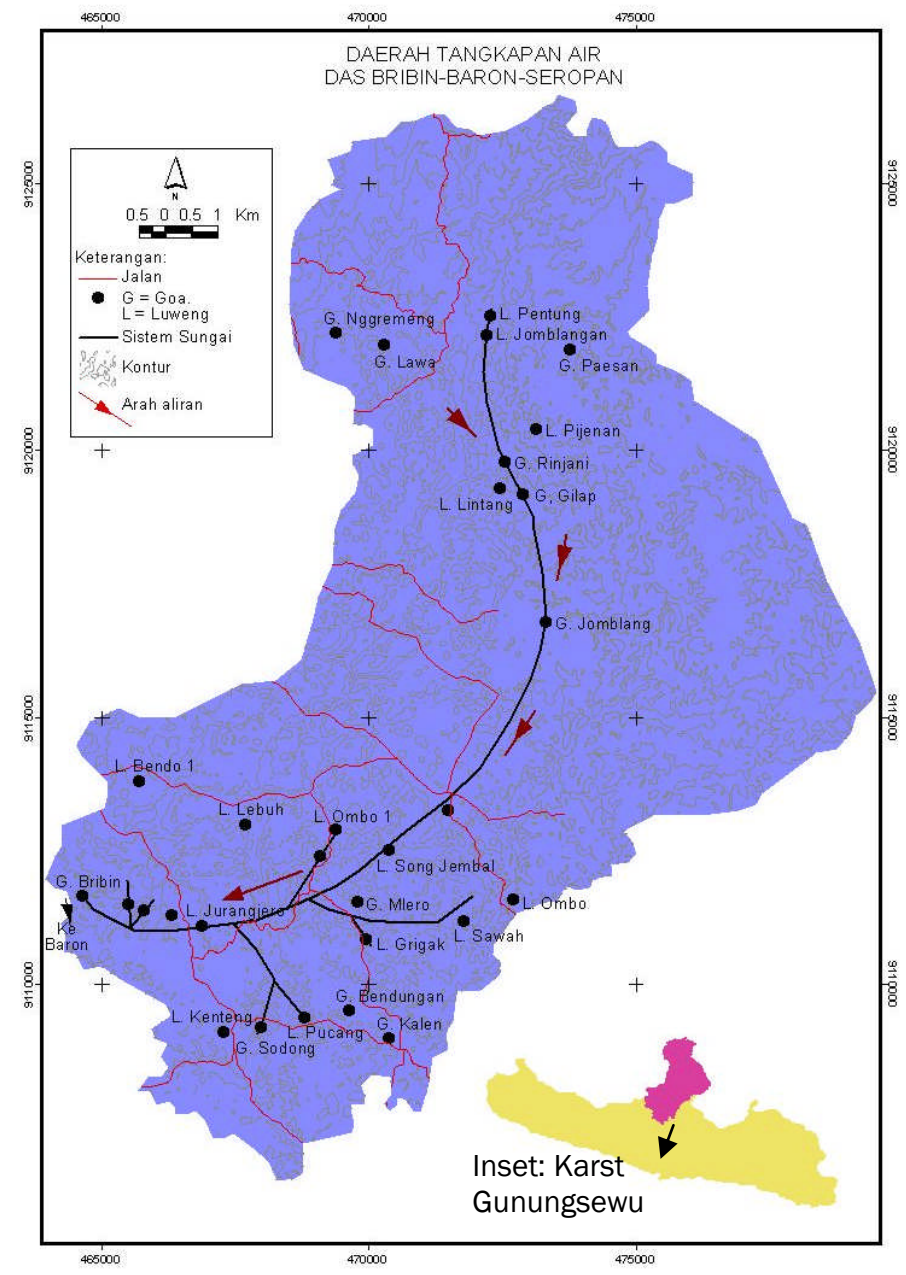

Gambar 4. Daerah tangkapan air Sungai Bribin-Baron-Seropan (Adji, 2000) 
Ancaman kekeringan di Kawasan Karst Gunungsewu dapat diketahui dengan mencermati variabilitas hujan yang terjadi berdasarkan data hujan tahun 1952 hingga 2009. Meskipun sebagian besar hujan tahunan yang terjadi relatif tetap antara 1251 hingga $2500 \mathrm{~mm}$, dan hanya sebagian kecil peristiwa ekstrim yang terjadi diluar itu, akan tetapi secara variabilitas kondisi hujan yang ekstrim selalu terjadi diantara beberapa kondisi normal dalam kurun waktu tertentu atau dengan kata lain menunjukkan periode ulang. Kondisi ekstrim ini disebabkan oleh pengaruh El Nino dan La Nina. Dalam pembahasan mengenai bencana kekeringan, periode ulang El Nino merupakan indikator bahwa bencana kekeringan masih terus mengancam dan akan terjadi kembali pada masa yang akan datang. Variabilitas hujan yang terjadi di Kawasan Karst Gunungsewu antara tahun 1952 hingga 2009 ditunjukkan oleh Gambar 5.

Sebagaimana telah diuraikan diatas, bukit karst memiliki peran sangat penting sebagai regulator alami sistem hidrologi Karst Gunungsewu termasuk di daerah tangkapan air Sub-Sistem Bribin-Baron-Seropan (DAS Bawah Tanah Bribin-Baron). Oleh karena adanya peran bukit karst tersebut, Sungai Bawah Tanah Bribin-Baron dapat mengalir sepanjang tahun dengan debit yang cukup besar. Di beberapa tempat saat ini telah diupayakan pemompaan air dari sungai bawah tanah tersebut untuk mencukupi kebutuhan masyarakat.

Namun demikian dewasa ini kelestarian bukit karst banyak menghadapi ancaman, terutama dari banyaknya aktivitas penambangan batugamping. Pusat kegiatan penambangan batugamping yang berada di sebagian besar wilayah Kecamatan Ponjong terletak pada daerah tangkapan hujan Sungai Bribin-Baron dan bahkan tepat berada di atas alur sungai utama Bribin. Selain itu banyak terdapat lokasi sisa penambangan dengan bukit karst yang sudah hilang tanpa usaha konservasi yang sesuai. Terpusatnya penambangan di lokasi ini adalah karena banyaknya bukit karst yang tersusun oleh batugamping tipe chalky limestone yang merupakan bahan baku berkualitas baik untuk bahan bangunan, industri kimia, industri kosmetik, serta untuk bahan industri lem dan semir sepatu. Jika mengacu pada nilai hidrologis bukit karst, kegiatan penambangan dengan memangkas bukit karst akan sangat signifikan mengurangi simpanan air yang pada akhirnya mengurangi debit Sungai Bribin (Adji, 2010). 


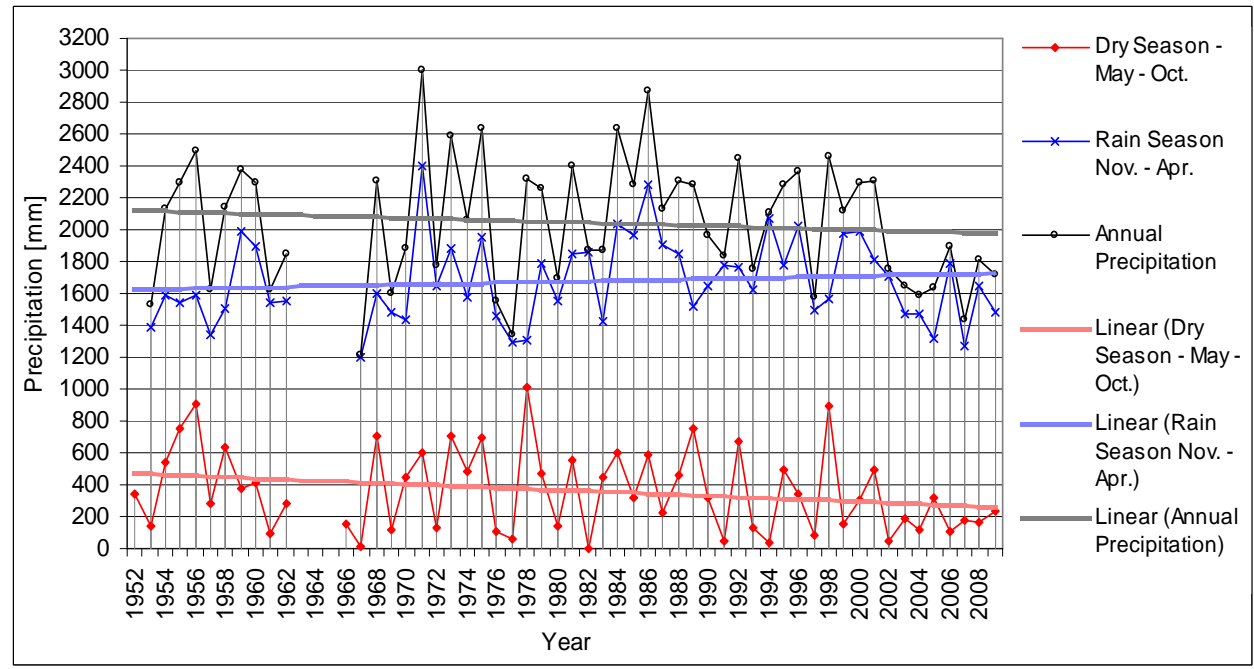

Gambar 5. Variabilitas hujan di Kawasan Karst Gunungsewu (Brunsch dkk, 2011)

\section{Konservasi Bukit Karst}

Mengingat pentingnya peranan bukit karst dalam mengatur sistem hidrologi di daerah Karst Gunungsewu, khususnya di DAS bawah tanah BribinBaron, perlu dilakukan tindakan konservasi terhadap bukit karst tersebut. Tindakan konservasi ini sekaligus juga sebagai upaya mitigasi untuk mengurangi dampak akibat bencana kekeringan pada saat kemarau panjang akibat El Nino. Menurut UU RI No 24 Tahun 2007 tentang Penanggulangan Bencana, mitigasi bencana merupakan serangkaian upaya untuk mengurangi risiko bencana, baik melalui pembangunan fisik maupun penyadaran dan peningkatan kemampuan menghadapi ancaman bencana. Sedangkan konservasi pada hakikatnya adalah mengelola dan memanfaatkan potensi sumberdaya yang ada secara optimum dengan memperhatikan aspek kelestarian sumberdaya tersebut. Apabila telah terjadi kerusakan, maka perlu dilakukan tindakan-tindakan rehabilitasi.

Konservasi kawasan karst merupakan isu yang telah banyak diperbincangkan baik dalam skala nasional maupun internasional. World Commision on Protected Area (WCPA) telah menerbitkan buku Guide Line for Cave and Karst Protection pada tahun 1997 (Haryono, 2001 ${ }^{\text {b }}$. Di Indonesia, pengelolaan dan konservasi kawasan karst juga telah diamanatkan dengan berpedoman pada keputusan menteri pertambangan dan energi Kepmen No 
1518 K/20/MPE/1999 serta keputusan menteri energi dan sumberdaya mineral No 1456 K/20/MEM/2000. Tindakan konservasi yang dapat diterapkan beragam bentuknya, sesuai dengan tipe, potensi, dan kondisi kawasan karst tersebut.

Tahap awal dalam tindakan konservasi adalah mengidentifikasi tipe karst di daerah tangkapan air DAS Bribin-Baron. Suatu tipe kawasan karst mempunyai karakteristik yang berkaitan dengan potensinya, hal ini merupakan dasar bagi penentuan arahan konservasi karst yang paling sesuai untuk diterapkan di wilayah tersebut. Haryono $\left(2000^{\mathbf{b}}\right)$ membedakan tipe kawasan berbatuan karbonat menjadi holokarst, mesokarst, dan non karst (Tabel 2). Mengacu pada klasifikasi tersebut, daerah tangkapan air DAS Bribin-Baron termasuk tipe holokarst yang dicirikan oleh adanya bukit karst, dolin, ponor, goa, dan sungai bawah tanah. Karst dengan ciri ini diarahkan untuk fungsi lindung dengan tetap mempertahankan keaslian ekosistem di dalamnya.

Setelah mengidentifikasi tipe karst, tahap selanjutnya adalah merencanakan bentuk konservasi yang lebih spesifik. Kegiatan yang dapat dilakukan antara lain (a) melakukan penataan kegiatan pertambangan; (b) melakukan rehabilitasi lahan bekas tambang; (c) melakukan pengelolaan zona epikarst, ponor/luweng; (d) melakukan pemberdayaan masyarakat daerah karst.

Tabel 2. Arahan Pengembangan Kawasan Berbatuan Karbonat

\begin{tabular}{|c|c|c|c|}
\hline Mintakat & Karakteristik & Fungsi utama & Kegiatan \\
\hline Holokarst & $\begin{array}{l}\text { Karst berkembang baik, } \\
\text { semua ciri-ciri karst (ponor, } \\
\text { dolin, uvala, kerucut dan } \\
\text { menara karst, goa-goa dan } \\
\text { sungai bawah tanah) dapat } \\
\text { ditemukan }\end{array}$ & $\begin{array}{l}\text { Fungsi lindung, } \\
\text { bentanglam dan } \\
\text { ekosistem yang ada di } \\
\text { dalamnya harus tetap } \\
\text { dipertahankan } \\
\text { keasliannya }\end{array}$ & $\begin{array}{l}\text { Telah berpenghuni: wisata, } \\
\text { pertanian terbatas, } \\
\text { perikanan danau dolin, } \\
\text { permukiman terbatas } \\
\text { Belum berpenghuni: wisata } \\
\text { terbatas }\end{array}$ \\
\hline Mesokarst & $\begin{array}{l}\text { Karst tidak berkembang } \\
\text { dengan baik, kenampakan } \\
\text { karst semua ciri-ciri karst } \\
\text { (ponor, dolin, uvala, kerucut } \\
\text { dan menara karst, goa-goa } \\
\text { dan sungai bawah tanah) } \\
\text { jarang ditemukan }\end{array}$ & $\begin{array}{l}\text { Fungsi penyangga, } \\
\text { bentangalam dapat } \\
\text { dirubah dengan } \\
\text { pertimbangan ketat }\end{array}$ & $\begin{array}{l}\text { Pertanian, perikanan, } \\
\text { tambang, permukiman, } \\
\text { atau industri dengan skala } \\
\text { kecil }\end{array}$ \\
\hline Non karst & $\begin{array}{l}\text { Batuan karbonat tidak } \\
\text { mempunyai ciri-ciri karst }\end{array}$ & Fungsi budidaya & $\begin{array}{l}\text { Semua kegiatan dapat } \\
\text { dilakukan }\end{array}$ \\
\hline
\end{tabular}

Sumber: Haryono $\left(2000^{b}\right)$ 
Konservasi Bukit Karst Sebagai Tindakan Mitigasi Kekeringan di Daerah Tangkapan Hujan Sub Sistem

Geohidrologi Bribin-Baron-Seropan, Karst Gunungsewu

\section{Penataan kegiatan pertambangan}

Penambangan batugamping merupakan ancaman utama bagi keberlanjutan fungsi hidrologis bukit karst, khususnya di daerah tangkapan air DAS Bribin-Baron. Oleh karena itu penambangan harus dilakukan secara hatihati serta memilih lokasi yang paling tepat, yaitu pada bukit yang belum banyak mengalami karstifikasi sehingga fungsi hidrologisnya belum cukup besar. Menurut Haryono $\left(2000^{\mathrm{b}}\right)$, penambangan harus diarahkan pada lokasi yang batuan karbonatnya tidak mengalami karstifikasi atau sedikit mengalami karstifikasi, sedangkan kawasan karst yang berkembang baik atau holokarst sama sekali tidak boleh ditambang. Tipe karst di daerah tangkapan air DAS Bribin-Baron termasuk kategori holokarst, oleh karena itu kegiatan penambangan sebaiknya tidak dilakukan sama sekali, sehingga bukit-bukit karst tetap dibiarkan dalam kondisi alami untuk mempertahankan fungsi hidrologisnya. Karst dengan tipe Holokarst yang memiliki banyak goa, lubanglubang kecil, sungai bawah permukaan, dan mataair harus dihindari untuk ditambang (Vermeulen dan Whitten, 1999 dalam Sutikno dan Haryono, 2000 ${ }^{\mathrm{b}}$ ).

\section{Rehabilitasi lahan bekas tambang}

Meskipun tidak sesuai untuk tambang, batugamping di daerah tangkapan air DAS Bribin-Baron pada kenyataannya telah lama ditambang. Sisa aktivitas penambangan dapat dijumpai pada lahan-lahan bekas galian tambang, baik yang masih nampak berbentuk bukit ataupun yang bukitnya telah habis sama sekali. Kondisi ini tentu menyebabkan terganggunya fungsi hidrologis, oleh karena itu perlu dilakukan tindakan rehabilitasi lahan bekas tambang. Rehabilitasi pada dasarnya mengembalikan siklus atau proses alam kembali atau mendekati keadaan semula atau alamiah (Sutikno dan Haryono, 2000). Menurut Haryono $\left(2000^{b}\right)$ kegiatan rehabilitasi dapat dilakukan dengan melakukan pembuatan teras, penghutanan kembali, maupun dibiarkan secara alami.

Pembuatan teras pada dasarnya tidak hanya dilakukan untuk rehabilitasi bukit karst yang telah ditambang saja, akan tetapi juga pada bukit karst yang digunakan untuk tegalan. Pembuatan teras selain mengurangi erosi juga dapat menghambat limpasan permukaan, sehingga resapan air ke zona epikarst lebih besar. Menurut Haryono $\left(2000^{b}\right)$, pada bukit bekas tambang teras dibuat di lahan-lahan miring serta tebing. Teras akan mengembalikan fungsi hidrologis dan geomorfologi mendekati kondisi alami. 
Penghutanan kembali berkaitan dengan pemulihan fungsi hidrologis, geomorfologi, dan biokimia. Penghutanan kembali merupakan tindakan konservasi yang telah banyak dilakukan. Dengan adanya hutan maka diharapkan proses geomorfologi yang berupa pelarutan batugamping akan dapat berlangsung kembali secara alami. Hutan menghasilkan $\mathrm{CO}_{2}$ dalam tanah yang apabila bereaksi dengan $\mathrm{H}_{2} \mathrm{O}$ akan dapat melarutkan batugamping $\left(\mathrm{CaCO}_{3}\right)$. Dengan adanya proses karstifikasi seperti dalam kondisi alami maka diharapkan terbentuk retakan-retakan dekat permukaan yang dapat menyimpan airtanah.

Bentuk rehabilitasi lainnya yang dapat dilakukan adalah dibiarkan secara alami, yaitu dilakukan dengan membiarkan tanpa campur tangan manusia untuk jangka waktu yang lama. Pelaksanaan ini memerlukan pengawasan yang ketat dan harus terkait dengan kawasan di sekitarnya (Haryono, 2000 ${ }^{\mathrm{b}}$ ). Rehabilitasi yang dibiarkan secara alami dapat dilakukan pada lahan yang tidak terlalu banyak dirusak, baik itu bekas tambang, lahan pertanian, maupun lahan gundul akibat penebangan pohon.

\section{Pengelolaan Zona Epikarst, Ponor/Luweng}

Bukit karst merupakan tandon air yang cukup besar di daerah karst. Di Indonesia diperkirakan 30-40\% air berasal dari kawasan karst (Martisasi, 2012) yang antara lain tersimpan dalam bukit karst ini. Kemampuan bukit karst menyimpan air tidak terlepas dari fungsi epikarst dan ponor/luweng yang memberikan input air ke sistem bawah permukaan. Oleh karena memiliki peran yang cukup penting, maka tindakan konservasi bukit karst juga perlu dilakukan dengan mengelola zona epikarst dan ponor/luweng. Konservasi epikarst dapat dilakukan dengan menanam rumput di permukaan. Rumput berperan sebagai penyaring sehingga hanya sedimen saja yang mengendap pada epikarst, sampah-sampah dapat dihalangi karena apabila menimbun epikarst akan mengurangi kapasitas simpanan airtanah. Selain itu apabila akan membuat teras untuk tegalan, diupayakan tidak sampai memotong zona epikarst ini karena akan mengurangi kapasitas simpanan airtanah.

Ponor/luweng dapat berperang sebagai jalur masuknya air ke sistem bawah permukaan. Oleh karena itu selain epikarst, ponor/luweng juga harus dilindungi dengan tujuan agar sampah dan polutan tidak masuk dan menyumbatnya. Hal ini berkaitan dengan kuantitas dan kualitas sumberdaya air yang akan masuk ke sistem bawah permukaan. Beberapa tindakan yang dapat dilakukan untuk mengkonservasi ponor/luweng menurut Haryono (2001) antara lain: (a) menanami rumput dan tanaman lain pada radius 30 meter untuk 
menyaring sedimen; (b) membuat bangunan/tumpukan batu di ponor/luweng untuk mencegah mulut ponor semakin besar; (c) tidak membuang sampai, limbah, bangkai binatang ke dalam ponor/luweng; (d) membersihkan kembali ponor/luweng apabila telah digunakan untuk pembuangan.

\section{Pemberdayaan Masyarakat Daerah Karst}

Pada akhirnya masyarakat merupakan pihak yang memiliki peran paling besar dalam mendukung keberhasilan konservasi bukit karst. Untuk itu masyarakat perlu dibekali dengan pemahaman dan pengetahuan mengenai kawasan karst, karakteristiknya, dan tindakan-tindakan dalam konservasi yang dapat dilakukan. Kearifan lokal yang telah diwariskan turun temurun yang berhubungan dengan pelestarian kawasan karst juga perlu dipertahankan.

Selain itu pemberdayaan juga dilakukan berkaitan dengan mata pencaharian masyarakat. Pada kenyataannya hingga saat ini masih banyak masyarakat yang menggantungkan hidup dari sektor pertambangan. Apabila daerah tangkapan air DAS Bribin-Baron yang bertipe holokarst tidak boleh ditambang, maka perlu adanya solusi perubahan mata pencaharian masyarakat dari tambang ke sektor lain. Bentuk kegiatan di luar tambang yang dapat diberdayakan sebagai mata pencaharian masyarakat antara lain mengembangkan ekowisata, pertanian, peternakan, dan perikanan. Kawasan karst bertipe holokarst yang memiliki banyak keunikan bentanglahan sangat potensial untuk dikembangkan sebagai tujuan ekowisata. Pertanian dan perikanan pada telaga yang telah banyak dilakukan juga dapat terus dikembangkan.

\section{Penutup}

Perbukitan karst memiliki peran sangat penting dalam mengatur sistem hidrologi di kawasan karst. Daerah Aliran Sungai Bribin-Baron yang merupakan Sub-Sistem Bribin-Baron-Seropan, memiliki debit cukup besar dan dapat mengalir sepanjang tahun karena air hujan yang ditangkap tersimpan terlebih dahulu pada bukit-bukit karst tersebut, baru kemudian teratus ke sungai bawah tanah secara perlahan-lahan. Dalam menghadapi kemarau panjang agar kebutuhan akan sumberdaya air tetap tercukupi maka fungsi hidrologis bukit karst tersebut harus dipertahankan. Tindakan konservasi yang dapat dilakukan antara lain (a) menjaga dan mengelola bukit-bukit karst yang masih alami sesuai peruntukannya dengan mengacu pada tipe kawasan karst, (b) mengatur penambangan batugamping, (c) rehabilitasi lahan bekas tambang, (d) mengelola zona epikarst dan ponor/luweng, serta (d) melakukan pemberdayaan masyarakat sebagai pengelola dan pelaksana tindakan konservasi tersebut. 


\section{Daftar Pustaka}

Adji, Tjahyo Nugroho. 2010. Kondisi Daerah Tangkapan Sungai Bawah Tanah Karst Gunungsewu dan Kemungkinan Dampak Lingkungannya terhadap Sumberdaya Air (Hidrologis) Karena Aktivitas Manusia. Seminar Pelestarian Sumberdaya Airtanah Kawasan Karst Gunungkidul. UGK BP DAS SOP.

Brunsch, Andrea., Adji, Tjahyo Nugroho., Stoffel, Daniel., Ikhwan, Muhammad., Oberle, Peter., dan Nestmann, Franz. 2011. Hydrological Assessment of A Karst Area in Suthern Java With Respect to Climate Phenomena. Asian Trans Disciplinary Karst Conference. Fakultas Geografi Universitas Gadjah Mada. Yogyakarta 7-10 Januari 2011.

Ford, Derek dan Williams, Paul. 2007. Karst Hydrogeology and Geomorphology. Sussex: John Wiley and Sons.

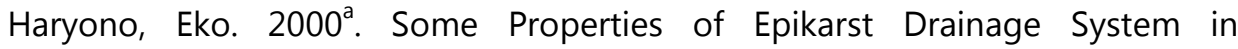
Gunungkidul Regency, Yogyakarta, Indonesia. Indonesian Journal of Geography 32 (79-80): 75-86.

Haryono, Eko. 2000 . Sumberdaya Alam di Kawasan Pesisir dan Pulau-Pulau Kecil Berbatuan Karbonat: Telaah Singkat Mengenai Potensi, Arahan Pengembangan, Konservasi dan Rehabilitasi. Seminar Nasional Pengelolaan Ekosistem Pantai dan Pulau-Pulau Kecil dalam Konteks Negara Kepulauan. Fakultas Geografi Universitas Gadjah Mada.

Haryono, Eko. 2001 a . Nilai Hidrologis Bukit Karst. Makalah pada Seminar Nasional Eko-Hidrolik. Teknik Sipil Universitas Gadjah Mada. Yogyakarta 28-29 Maret 2001.

Haryono, Eko. 2001 ${ }^{\mathrm{b}}$. Konservasi Kawasan Karst. Seminar Pemberdayaan Sumberdaya Wilayah kabupaten dan Kota untuk Pengembangan Ekonomi Kerakyatan dalam Memasuki Otonomi Daerah dalam rangka Dies Fakultas Geografi UGM XXXVIII. Fakultas Geografi Universitas Gadjah Mada.

Haryono, Eko. 2011. Introduction Gunungsewu Karst Java-Indonesia. Field Guide Asian Trans-Disciplinary Karst Conference 2011. Fakultas Geografi Universitas Gadjah Mada. Yogyakarta 7 - 10 Januari 2011.

Haryono, Eko dan Day, Mick. 2004. Landform Differentiation Within the Gunungsewu Kegelkarst Java Indonesia. Journal of Cave and Karst Studies V 66 (2): 62-69. 
Konservasi Bukit Karst Sebagai Tindakan Mitigasi Kekeringan di Daerah Tangkapan Hujan Sub Sistem

Geohidrologi Bribin-Baron-Seropan, Karst Gunungsewu

MacDonald and Partners. 1984. Greater Yogyakarta - Groundwater Resources Study. Vol 3C: Cave Survey. Yogyakarta: Directorate General of Water Resources Development Project.

Martisari, Fitrisia. 2012. Menambang Karst, Mengubur Kehidupan. Dalam Harian Kompas Jumat 4 Mei 2012 Halaman 33.

Nestmann, Franz., Oberle, Peter., Ikhwan, Muhammad., Klingel, Phillip., Stoffel, Daniel., dan Solichin. 2011. Development of Underground Hydropower Systems for Karst Areas - Pilot Study Java, Indonesia. Asian Trans Disciplinary Karst Conference. Fakultas Geografi Universitas Gadjah Mada. Yogyakarta 7-10 Januari 2011.

Sutikno dan Haryono, Eko. 2000. Perlindungan Fungsi Kawasan Karst. Seminar Perlindungan Penghuni Kawasan Karst Masa Lalu, Masa Kini, dan Masa Yang akan Datang terhadap Penurunan Fungsi Lingkungan Hidup. PSLM Universitas Sebelas Maret. 